Impacts of human interventions on water quality of upper Ganga River near Haridwar, Uttarakhand: A

\title{
GIS-based analysis
}

Pradip Kumar Maurya ${ }^{1 *}$, Sk Ajim Ali², Ateeque Ahmad², Krishna Kumar Yadav ${ }^{3}$

${ }^{1}$ Department of Zoology and Environmental Science Gurukula Kangari Vishwavidyalaya,

$$
\text { Haridwar- 249404, India }
$$

${ }^{2}$ Department of Geography, Faculty of Science, Aligarh Muslim University, Aligarh, U.P. India

${ }^{3}$ Faculty of Science and Technology, Madhyanchal Professional University, Ratibad, Bhopal, 462044, India

\section{*Corresponding author: pk.maurya86@gmail.com}

\begin{abstract}
The water quality of the river is becoming deteriorated due to human interference. It is essential to understand the relationship between human activities and land-use types to assess the water quality of a region. GIS has the latest tool for analyzing the spatial correlation. Land use land cover and change detection is the best illustration to show the human interactions on land features. The study assessed water quality index of upper Ganga River near Haridwar, Uttarakhand and spatially correlated them with changing land use to reach a logical conclusion. At the upper course of Ganga along $78 \mathrm{Km}$ long from Kaudiyala to Bhogpur, water samples were collected from five stations. For water quality index the physicochemical parameters like pH, EC, DO, TDS, $\mathrm{CaCO}_{3}{ }^{-}, \mathrm{CaCO}_{3}$, $\mathrm{Cl}^{-}, \mathrm{Ca}^{++}, \mathrm{Mg}^{++}, \mathrm{Na}^{+}, \mathrm{K}^{+}, \mathrm{F}^{-}, \mathrm{Fe}_{2}^{+}$were considered. The result of the spatial analysis was evaluated through error estimation and spatial correlation. The root mean square error between spatial land use and water quality index of selected sampling sites was estimated as 0.1443 . The spatial correlation between land-use change and sitewise differences in water quality index has also shown a high positive correlation with $\mathrm{R}^{2}=0.8455$. The degree of positive correlation and root mean square error has strongly indicated that the water quality of the river at the upper course of Ganga is highly impacted through human activities.
\end{abstract}

Keywords: Physico-chemical parameters, water quality index, land use land cover, GIS integration, special correlation

\section{Introduction}

Rivers are the natural gift which is highly vulnerable to land-use change and anthropogenic activities. Due to undesirable human activities, the pollution of river water has become a major environmental concern $[1,2]$. Human interventions are directly or indirectly reflected to land use characteristics. The land use change and water quality management understanding is very important from the management of water quality, land 
degradation and soil quality by human interference [3, 4]. Ganga is the holiest and important river system in India. From ancient time Ganga is directly or indirectly affected through human intervention [5]. Initially civilization and economic activities evolved around the Ganga and with growing industrialization recently the whole river system impacted by various human activities like bathing, washing clothes, the bathing of animals, transmitting agricultural sewage, and dumping of various harmful wastes [6-11]. This situation was limited in the middle and lower course of Ganga but recently many live stations at upper course also declared as unfit for drinking or other human uses. Different types of tourism activities, agricultural development, deforestation, and constructional activities are greatly vulnerable to river water exploitation [12-14]. Hence, long term land-use changes and human intervention are the significant factors for deteriorating the quality of water [15]. The deterioration of river water quality due to unaware human intervention has now become a key environmental concern [2]. Human activities are best depicted through the land use characteristics and its changes phenomena [4]. It is important to correlate land use characteristics and water quality to better understand the relationship between them and think for better management to minimize the pollution rate [16]. With the passage of time, developmental activities of communities, and unaware usage of water resources create a threat to monitoring water [17]. In addition, unwanted and waste materials from different sources can also cause surface water as well as groundwater pollution [18].

Ganga is the major river of Indian, It originates from Gaumukh ice cave of the Gangotri Glacier and with covering a drainage basin area of $8,61,404 \mathrm{~km}^{2}$, falls into the Bay of Bengal after crossing the length of more than $2525 \mathrm{~km}$ over the state of Uttarakhand, Uttar Pradesh, Bihar, Jharkhand, and West Bengal [8]. Due to human faith, Ganga receives billion of people's pressure every year for purifying soul, antimicrobial and medicinal relive [19-20]. Various famous cities like Haridwar, Kanpur, Allahabad, Varanasi, Patna, and Kolkata are situated in the bank of river Ganga From Gaumukh to Rishikesh it flows on hills of Himalayas and afterward, it comes in the Gangetic plains and then enters into the Bay of Bengal, and based on this the whole flowing course of Ganga can be divided into three parts i.e. upper, middle and lower plains [21]. The Ganga at the middle and lower course is heavily polluted due to the industrialization, rapid urbanization, and increasing population along the rivers have put tremendous pressure on water resources and their quality [22-25.]. It also passes along 29 class-I cities, 23 class-II cities and approximately 50 towns because of which different types wastes such as industrial, sewage, etc. are released into this and may destroy the river eco-system and its natural quality [26-28]. It was a known fact that the Ganga near a major town like Varanasi, Allahabad, and Kolkata is highly polluted and strictly prohibited for drinking purpose even after purified [29]. But the water at the upper 
Himalayan course was fresh and under the acceptable limit of drinking and other uses. Recently, human intervention in the Himalayan ecosystem including deforestation, agricultural activities, tourism and urbanization generally alter the natural balance which impact the land surface characteristics, water surface temperature, and changes in physicochemical parameters of water [30-35].

Water quality monitoring has one of the highest priorities in environmental protection policy [36]. Many researchers have already focused on the current status of Physico-chemical characteristics of water for monitoring and assessment [37-39]. The Government of India has also initiated many programs and action plan to reduce the level of pollution of Ganga and spent millions of rupees in varies stage of implementation. But no positive result was found [40]. For example, the Ganga Action Plan or GAP was a program launched by Rajiv Gandhi in 1986 with the main aim to reduce the pollution level and spent 9017.1 million rupees. But it was considered as failure and withdrawn in 2000. The National Ganga River Basin Authority (NGRBA) was established in 2009 for cleaning and conservation but after 10 years of establishment of NGRBA, the quality of river Ganga does not improve to desire level [41]. National Democratic Alliance government launched Namami Gange in mid-May 2015, another plan with new hope to conserve the holy water of Ganga and made deadline 2019 for great improvement. But even after four years of an allotment of Rs 22,000 crores, the program is far from being a success [42]. Therefore, there is an urgent need to conduct more case studies for micro-level analysis to detect local factors affecting water quality.

In this study, the effort was made to detect the local land-use change and spatially correlate with surface water quality. The anthropogenic activities are the chief factor for land-use change which also responsible for breaking down the local biological system and thereafter it affects the local environmental component like soil, air, and water. When we talk about water pollution and deterioration of its quality, it is a linear process. The pollutants or unwanted materials first affects its chemical quality and then systematically destroys the community disrupting the delicate food web. In India, it is reported that about $70 \%$ of the available water is polluted. Therefore, looking toward such problems, the present study was aimed to find a linear relationship between land use and water quality at the upper course of river Ganga.

\section{Materials and Methods}

\subsection{Study area}

The present study covers the upper Ganga River from Kaudiyala to Bhogpur village. Shivpuri, Rishikesh, and Haridwar are one of the important tourist spots of Uttarakhand. It is situated on the right bank of Ganga and at the foothills of Shivalik ranges. It is one of the most ancient towns and a very important pilgrim centre of India, 
where people from all over the country come round the year to have a dip in the river Ganga. On an average around two lakh, people visit Haridwar and Rishikesh city daily. It is closely interwoven with aesthetic culture and tradition and the health, and years the river has been indiscriminately polluted.

Kaudiyala is a village located $40 \mathrm{Km}$ east to Rishikesh and famous for river rafting and beach camping. Shivpuri is only $16 \mathrm{Km}$ from Rishikesh. These two sites are relatively least impacted by human intervention and these are only crowded with adventure lovers. Rishikesh and Haridwar are famous for their religious significance. There are many temples and ashrams beside the river Ganga and millions of people visit these places every day for religious faith. These two places are overcrowded and many constructional activities going on to facilitate the increasing peoples day by day. The last sampled station i.e. Bhogpur is located at Himalayan foothill (about 250m). In this portion, the water of Ganga is highly used for cultivation in the surrounding areas (Fig. 1).
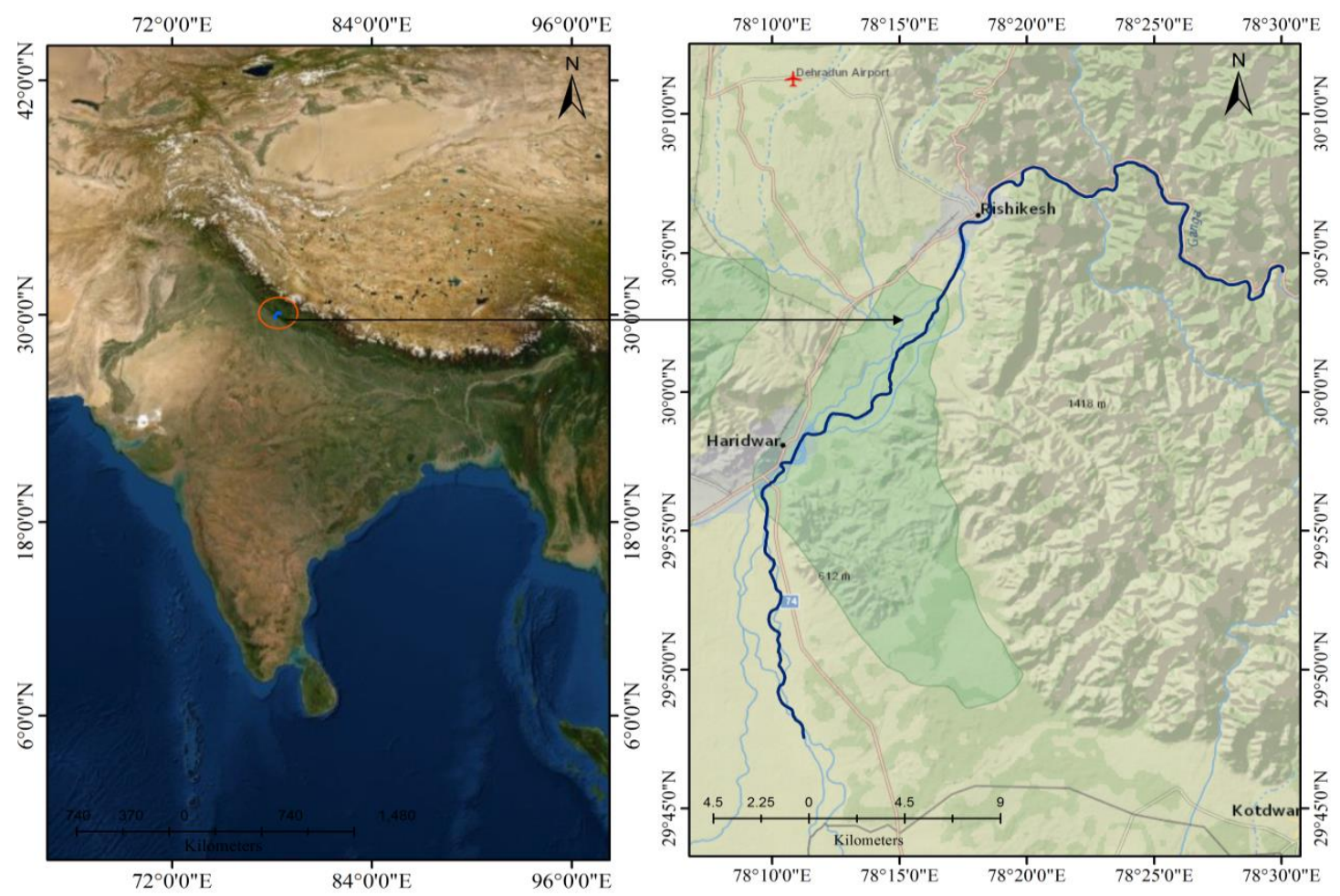

Fig. 1 Map showing the case study area, upper Ganga near Haridwar, Uttarakhand

\subsection{Decision model}

The decision model was designed to show the interlinks between human interactions through land use land cover change and water quality. The model shows three components and their relationship. The negative impact of human activities may cause the degradation of land features, i.e. major changes in land use, land cover which have great consequences on main abiotic component of the earth i.e. water bodies. The model was structured in the sequential way to determine the causes of deterioration of water quality. The model was perception based and prepared to clarify 
the presumption that human interactions have significant role in modifying the land features which directly degrade the natural quality of water and make it unfit for human consumption and other uses including agriculture (Fig. 2).

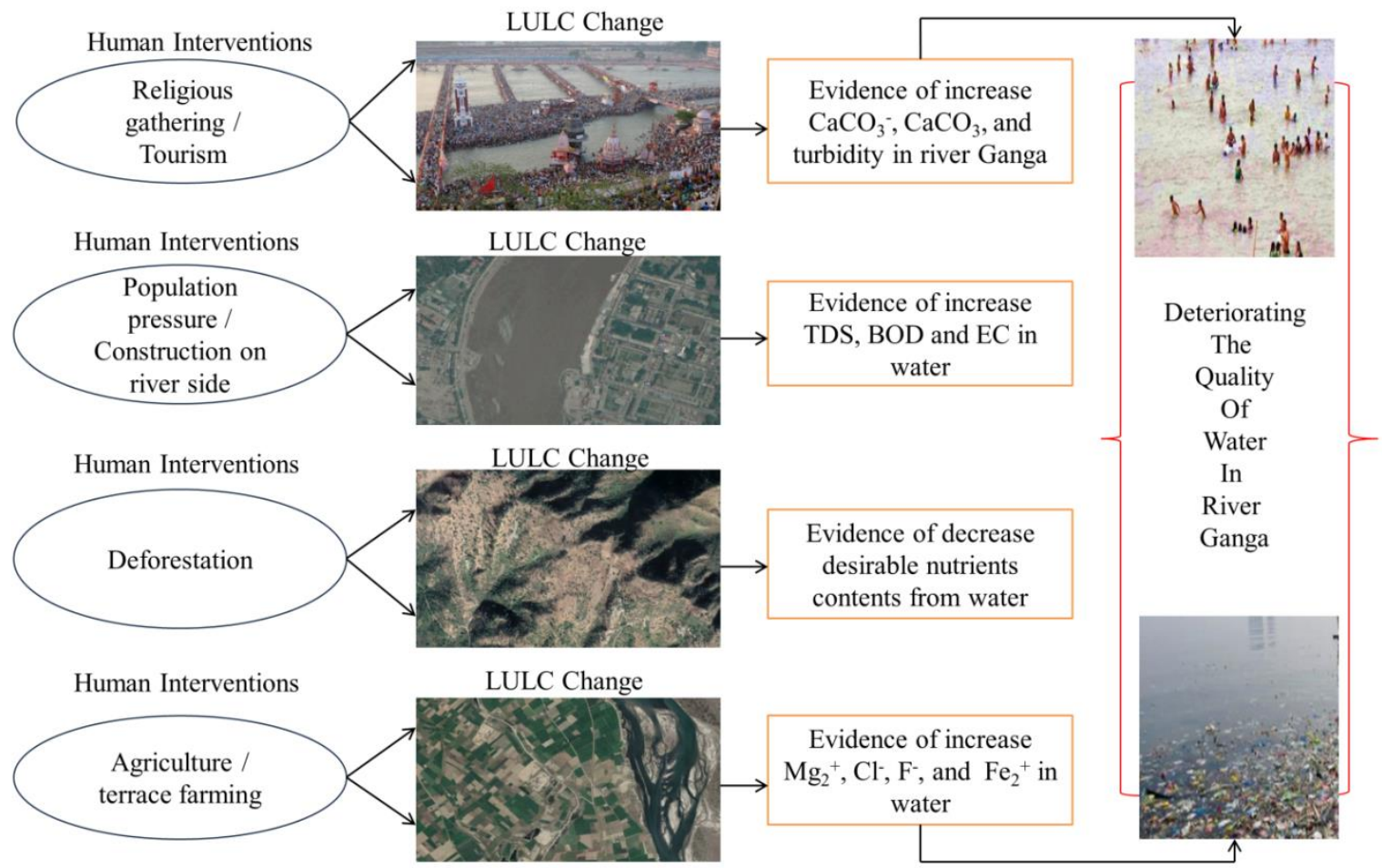

Fig. 2 Decision model for assessing the impacts of human interventions and destruction of water quality

Thus, keeping the decision model in mind the sample sites were chosen for water sample collection. The sample sites were selected thus they can cover both places where maximum and minimum human interventions found. Concomitantly, land use land cover mapping and change detection analysis was done to identify the impacts of such human intervention on nearly water quality.

\subsection{Sample sites}

The most relevant factor regarding the selection of this study area and sampled sites are to identify the human intervention on the river at the Himalayan region and its effect on water. From the upper course of river Ganga, 5 sites were chosen to collect water samples by considering the places where least to high human intervention are observed along $78 \mathrm{Km}$ long distance from Kaudiyala (436m) to Bhogpur (246m) (Fig. 3).

Site-I - The site on River is situated near Kaudiyala, located at $30^{\circ} 4^{\prime} 25.15^{\prime \prime} \mathrm{N}$ to $78^{\circ} 30^{\prime} 5.39^{\prime \prime} \mathrm{E}$, victimized with the human disturbances to some extent and received waste from cattle washing, vehicle washing, idol immersion, cremation, nirmalya immersion and also used for fishing activities and botting in this area. 
Site-II - The site Shivpuri is located at $30^{\circ} 8^{\prime} 7.78^{\prime \prime} \mathrm{N}$ to $78^{\circ} 23^{\prime} 27.27^{\prime \prime E}$, representing the lotic systems and less disturbed by various anthropogenic activities, although some tourist activist increasing day by day. The site receiving the sewage, dirt form washed clothes, vehicles cleaning, idol immersion and animal washing, fishing and other several activities in the least manner.

Site-III - The site Rishikesh is situated at $30^{\circ} 4^{\prime} 59.57^{\prime \prime} \mathrm{N}$ and $78^{\circ} 17^{\prime} 26.54^{\prime \prime} \mathrm{E}$, many human disturbances on river water are seen there due to Rishikesh is a holy place and people from whole over the country and from abroad come here for religious peace. The overpopulation and their contact with Ganga are the main reason for river water pollution here.

Site-IV - The site Haridwar is an ancient city and important Hindu pilgrimage site in Uttarakhand state, where the River Ganges exits the Himalayan foothills. The largest of several sacred ghats (bathing steps), har Ki Pauri hosts a nightly Ganga Aarti (river-worshipping ceremony) are there in which tiny flickering lamps are floated off the steps. Worshipers fill the city during major festivals like the annual Kanwar Mela. During this time one can detect the pollutants in water by its natural quality and colour.

Table 1 Descriptions of sampling sites on the basis of geocoordinate

\begin{tabular}{|l|l|l|l|l|l|}
\hline Site & $\begin{array}{l}\text { Sampling } \\
\text { location }\end{array}$ & Latitude & Longitude & $\begin{array}{l}\text { Height above } \\
\text { MSL }\end{array}$ & Types of area \\
\hline S-1 & Kaudiyala & $30^{\circ} 4^{\prime} 25.15^{\prime \prime N}$ & $78^{\circ} 30^{\prime} 5.39^{\prime \prime} \mathrm{E}$ & $436 \mathrm{~m}$ & Hilly \\
\hline S-2 & Shivpuri & $30^{\circ} 8^{\prime} 7.78^{\prime \prime} \mathrm{N}$ & $78^{\circ} 23^{\prime} 27.27 " \mathrm{E}$ & $386 \mathrm{~m}$ & Hilly \\
\hline S-3 & Rishikesh & $30^{\circ} 4^{\prime} 59.57^{\prime \prime N}$ & $78^{\circ} 17^{\prime} 26.54 " \mathrm{E}$ & $341 \mathrm{~m}$ & Hilly \\
\hline S-4 & Haridwar & $29^{\circ} 56^{\prime} 47.30^{\prime \prime N}$ & $78^{\circ} 9^{\prime} 40.92^{\prime \prime} \mathrm{E}$ & $288 \mathrm{~m}$ & Plane \\
\hline S-5 & Bhogpur & $29^{\circ} 47^{\prime} 44.03 " \mathrm{~N}$ & $78^{\circ} 11^{\prime} 14.59 " \mathrm{E}$ & $246 \mathrm{~m}$ & Plane \\
& & & & & \\
\hline
\end{tabular}

Site-V - The site Bhogpur village is located at the downstream which is about $20 \mathrm{Km}$ towards South Haridwar district. Agriculture and animal husbandry are the main profession of a resident of this village and completely depend on river water. Different agricultural processing, irrigation, deforestation, etc. are large human intervention with Ganga's water in this site that makes more contamination in comparison to other sites. Detailed sample collection stations are illustrated below (Table 1). 


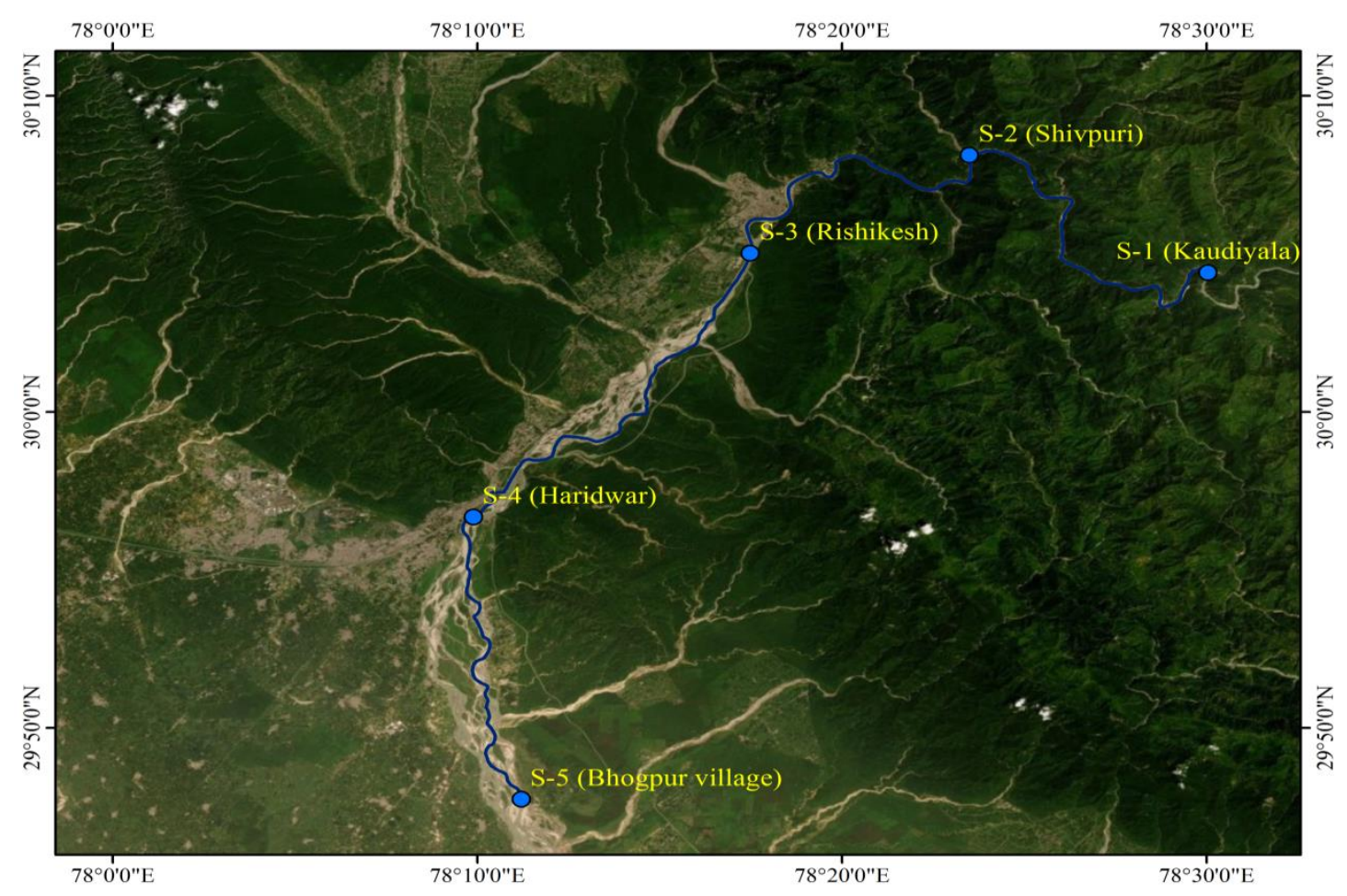

Fig. 3 Satellite image of selected sampling sites

\subsection{Sample collection}

Water samples were collected from selected sites during the months of January to December 2018. From the above sites, the water samples were collected in $2 \mathrm{~L}$ pre-cleaned polyethylene bottles. The water samples were collected for continuous monitoring involved comprehensive physicochemical analyses. The Physico-chemical parameters like pH, Electrical Conductivity (EC), Dissolved Oxygen (DO), Total Dissolved Solids (TDS), Total Alkalinity (TA), Total Hardness (TH), Chloride $\left(\mathrm{Cl}^{-}\right)$, Calcium $\left(\mathrm{Ca}^{+}\right)$, Magnesium $\left(\mathrm{Mg}^{+}\right)$, Sodium $\left(\mathrm{Na}^{+}\right)$and Potassium $\left(\mathrm{K}^{+}\right)$, Fluoride (as $\left.\mathrm{F}^{-}\right)$, Ferrous iron $\left(\mathrm{Fe}_{2}{ }^{+}\right)$of water samples were collected from river Ganga between 8.00 and 12.00 hours. The collected water samples were safely carried out and stored in the laboratory for further testing and analyzing.

\subsection{Physico-Chemical Analysis}

Parameters like pH, EC, TDS, and DO were estimated at the spot immediately after the collection of the samples whereas water analysis relating to other chemical factors was done in the laboratory and the mean testing result of different time period's analysis was used for water quality determination. Each sample was subjected to the concerned analytical (gravimetric/volumetric/calorimetric) procedure and the mean values of observations were taken. The Chemical analysis was carried out the following methods by [43], and standard analytical procedures 
as recommended of [44]. The detailed water sample parameters and standard value as recommended in the Bureau of Indian Standards [45] guideline are given below (Table 2).

Table 2 Selected physicochemical parameters and their standard limit as per recommended by BIS

\begin{tabular}{|c|c|c|c|c|}
\hline Parameters & Units & Method used for test & Desirable & Permissible \\
\hline Temperature & ${ }^{\circ} \mathrm{C}$ & Electrode & NA & NA \\
\hline $\mathrm{pH}$ & & Electrode & $6.5-8.5$ & $6.5-8.5$ \\
\hline Dissolved Oxygen (DO) & $\mathrm{mg} / \mathrm{l}$ & Modified Winker's method & 6 & NA \\
\hline COD & $\mathrm{mg} / \mathrm{l}$ & Closed reflux method & NA & NA \\
\hline BOD & $\mathrm{mg} / \mathrm{l}$ & Modified Winker's method & 3 & 6 \\
\hline Total Alkalinity (CaCo3-) & $\mathrm{mg} / \mathrm{l}$ & Titrimetric & 200 & 600 \\
\hline Total hardness $(\mathrm{CaCo} 3)$ & $\mathrm{mg} / \mathrm{l}$ & EDTA titrimetric & 300 & 600 \\
\hline Turbidity & NTU & Colorimetric & 5 & 10 \\
\hline Electrical conductivity (EC) & $\mu \mathrm{S} / \mathrm{m}$ & Conductivity-TDS meter & 2,000 & 3000 \\
\hline Total dissolved solids (TDS) & $\mathrm{mg} / \mathrm{l}$ & Conductivity-TDS meter & 1000 & 2000 \\
\hline Calcium $(\mathrm{Ca} 2+)$ & $\mathrm{mg} / \mathrm{l}$ & EDTA titrimetric & 75 & 200 \\
\hline Magnesium (Mg2+) & $\mathrm{mg} / \mathrm{l}$ & EDTA titrimetric & 30 & 100 \\
\hline Sodium $(\mathrm{Na}+)$ & $\mathrm{mg} / \mathrm{l}$ & Flame photometric & 100 & 200 \\
\hline Potassium $(\mathrm{K}+)$ & $\mathrm{mg} / \mathrm{l}$ & Flame photometric & 10 & 10 \\
\hline Chlorides (Cl-) & $\mathrm{mg} / \mathrm{l}$ & Argentometric titration & 250 & 1000 \\
\hline Fluoride (as F-) & $\mathrm{mg} / \mathrm{l}$ & Electrode & 1 & 1.5 \\
\hline Ferrous iron $(\mathrm{Fe} 2+)$ & $\mathrm{mg} / \mathrm{l}$ & Phenanthroline method & 0.3 & 1 \\
\hline
\end{tabular}

Note: the desirable and permissible limits are as per BIS 1998 [46] and 10500 (2012)

\subsection{Water quality index}

The assessment of water quality index (WQI) offers a comprehensive picture of the overall water quality of ground and surface water [47]. The increasing rate of population, urbanization, and industrialization are main responsible for degrading the water quality in developing countries like India [48]. Water quality index is referred to as the rating of different water parameters that reflects the composite influence of water quality [49]. 
Hence, WQI is required to calculate for assessing the suitability of ground/surface water for human consumption and another purpose of uses [50].

Table 3 Required computing WQI of relevant criteria of selected parameters

\begin{tabular}{|c|c|c|c|}
\hline Parameters & IS desirable limit (Sn) & Rank (Rn) & Unit weight (Wn) \\
\hline $\mathrm{pH}$ & 8.5 & 3 & 0.0681 \\
\hline Dissolved Oxygen (DO) & 6 & 2 & 0.0454 \\
\hline $\mathrm{BOD}$ & 3 & 3 & 0.0681 \\
\hline Total Alkalinity $\left(\mathrm{CaCO}_{3}{ }^{-}\right)$ & 200 & 2 & 0.0454 \\
\hline Total hardness $\left(\mathrm{CaCO}_{3}\right)$ & 300 & 3 & 0.0681 \\
\hline Turbidity & 5 & 2 & 0.0454 \\
\hline Electrical conductivity (EC) & 2000 & 3 & 0.0681 \\
\hline Total dissolved solids (TDS) & 1000 & 5 & 0.1136 \\
\hline Calcium $\left(\mathrm{Ca}_{2}^{+}\right)$ & 75 & 2 & 0.0454 \\
\hline Magnesium $\left(\mathrm{Mg}_{2}^{+}\right)$ & 30 & 3 & 0.0681 \\
\hline Sodium $\left(\mathrm{Na}^{+}\right)$ & 100 & 3 & 0.0681 \\
\hline Potassium $\left(\mathrm{K}^{+}\right)$ & 10 & 2 & 0.0454 \\
\hline Chlorides $\left(\mathrm{Cl}^{-}\right)$ & 250 & 3 & 0.0681 \\
\hline Fluoride $\left(\right.$ as $\left.\mathrm{F}^{-}\right)$ & 1 & 5 & 0.1136 \\
\hline Ferrous iron $\left(\mathrm{Fe}_{2}^{+}\right)$ & 0.3 & 3 & 0.0681 \\
\hline
\end{tabular}

In this study water quality index was calculated using 15 parameters namely, $\mathrm{pH}$, dissolved oxygen, biological oxygen demand, total alkalinity, total hardness, turbidity, electrical conductivity, total dissolved solids, calcium, magnesium, sodium, potassium, chlorides, fluoride, and ferrous iron in order to know the spatial variation of water quality. For calculating the water quality index from collected sampled data, there are different techniques used by researchers [51,52]. In this study, the QWI index was calculated using Horton's method of water quality. The WQI is calculated by using the expression given below;

$$
W Q I=\frac{\sum q n W n}{\sum W n}
$$

Where, 
$q n$ indicates the quality rating of $\mathrm{n}^{\text {th }}$ water parameter.

$W n$ is the unit weight of the same parameter.

The quality rating (qn) is calculated using the following expression;

$$
q n=\frac{\left(V_{n-} V_{i}\right)}{\left(V_{s-} V_{i}\right)} * 100
$$

Where,

$V_{n}$ is the estimated value of $\mathrm{n}^{\text {th }}$ water quality parameter at a given sample location.

$V_{i}$ refers ideal value for $\mathrm{n}^{\text {th }}$ parameter should be in pure water (e.g. for $\mathrm{pH}$ it will 7 and 0 for all other parameters)

$S_{n}$ defines the standard permissible value of $\mathrm{n}^{\text {th }}$ water parameter as per Bureau of Indian Standards [45] for each chemical parameter in $\mathrm{mg} / \mathrm{l}$ except for electrical conductivity $(\mu \mathrm{S} / \mathrm{m})$, turbidity $(\mathrm{NTU})$ and $\mathrm{pH}$.

The unit weight $\left(W_{n}\right)$ is computed using the following expression;

$$
W n=\frac{K}{S n}
$$

Where,

$\mathrm{S}_{\mathrm{n}}$ is the standard permissible value of the $\mathrm{n}^{\text {th }}$ parameter as recommended by BIS.

$K$ indicates the constant of proportionality and it is calculated by the expression given below;

$$
K=\frac{R n}{\Sigma R n}
$$

Where, $R n=1,2,3 \ldots \ldots . . n$

\subsection{Water quality standard and unit weights of parameters for usable purpose}

The water quality parameters are selected based on its direct involvement in deteriorating water quality for human consumption. The standards for the drinking water, recommended by the Indian Council of Medical Research (ICMR) and Indian Standards Institution (ISI) were considered for the computation of water quality index. For the purpose of calculation of WQI for the study area, 15 water quality parameters have been selected. They are $\mathrm{pH}, \mathrm{DO}, \mathrm{BOD}, \mathrm{CaCO}_{3}{ }^{-}, \mathrm{CaCO}_{3}$, Turbidity, EC, TDS, $\mathrm{Ca}_{2}{ }^{+}, \mathrm{Mg}_{2}{ }^{+}, \mathrm{Na}^{+}, \mathrm{K}^{+}, \mathrm{Cl}^{-}, \mathrm{F}^{-}$, and $\mathrm{Fe}_{2}{ }^{+}$. $\mathrm{The}$ standard values of water quality parameters and their corresponding ideal values and unit weights are given here

(Table 3). The values of some parameters are found above the permissible limits in some of the samples of the study area. The higher values of these parameters would increase the WQI value. The details of the IS standard of water quality index, status, and limit of possible usage is shown in the following table (Table 4). 
Table 4 The ranges of WQI, the corresponding status of water quality and their possible uses for drinking and irrigation suitability

\begin{tabular}{|l|l|l|l|}
\hline S.No & WQI & Status & Possible uses \\
\hline 1 & $<25$ & Excellent & Drinking, Irrigation and Industrial \\
\hline 2 & $25-50$ & Good & Domestic, Irrigation and Industrial \\
\hline 3 & $51-75$ & Fair & Irrigation and Industrial \\
\hline 4 & $76-100$ & Poor & Irrigation \\
\hline 5 & $101-150$ & Very Poor & Restricted use for Irrigation \\
\hline 6 & $>150$ & Unfit for Drinking & Proper treatment required before use \\
\hline
\end{tabular}

\subsection{Preparation of the land-use map}

Looking towards the main aim of this study i.e. show the relation of land use on water quality, it is presumed that the changing land use and particular activity have a great effect on water quality deterioration. Hence, it is required to prepare different period's land use map, detection of a change in land use and spatially correlate the water quality index with changing land features. For the same, the land use map was prepared for two different periods i.e. 2008 and 2018. The Landsat TM and OLI (L-5 and L-8) images were used which are available at USGS web portal (https://earthexplorer.usgs.gov/). Band 4, 3, 2 for TM and 7, 6, 4 for OLI were combined to create FCC image. Based on color composite and the real view from Google Earth Engine, the signatures were created and supervised image classification run in GIS environment for both 2010 and 2020 (Fig. 4 and Fig. 5). 


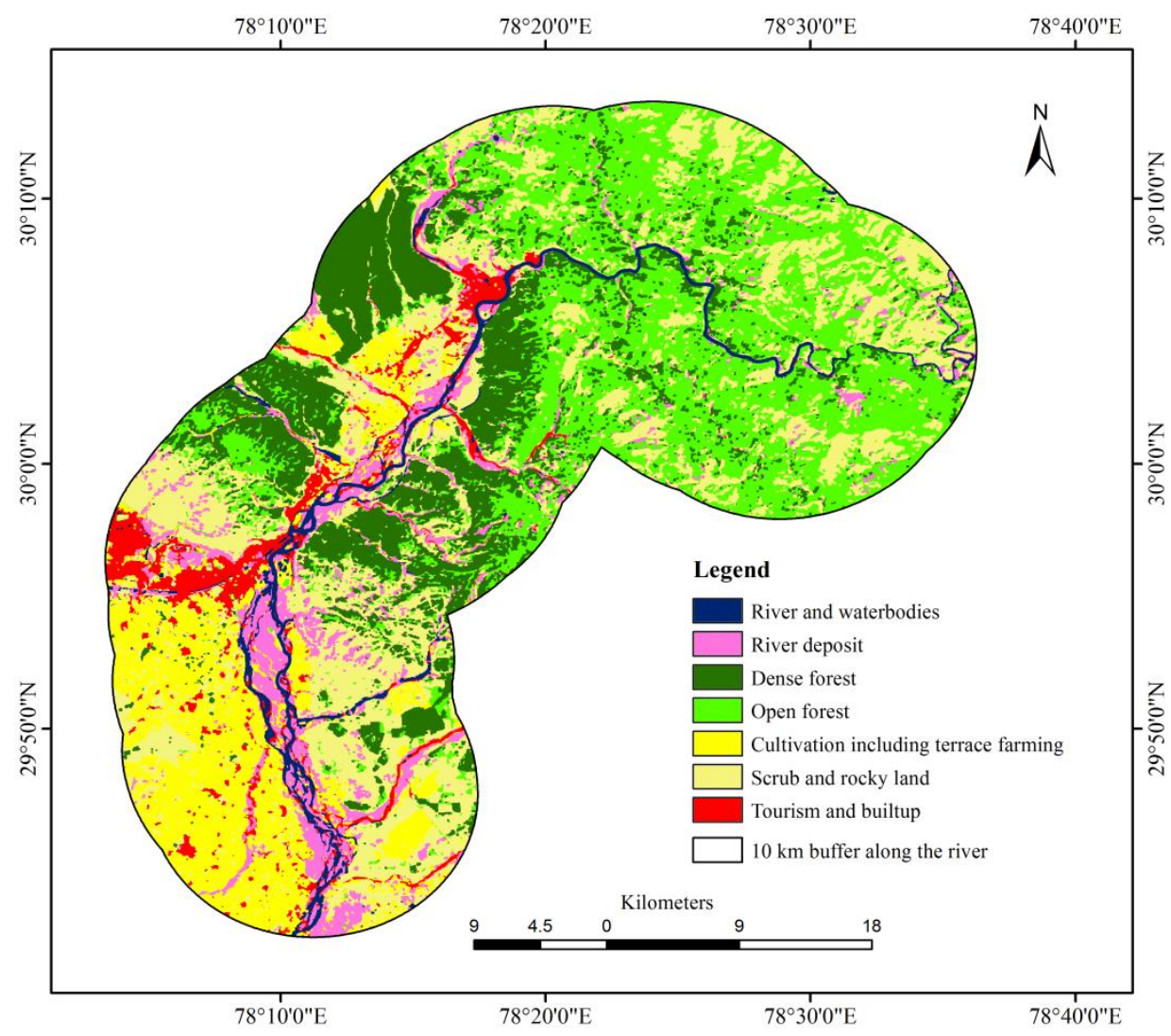

Fig. 4 Land-use map of 2010, derived from Landsat-5 TM

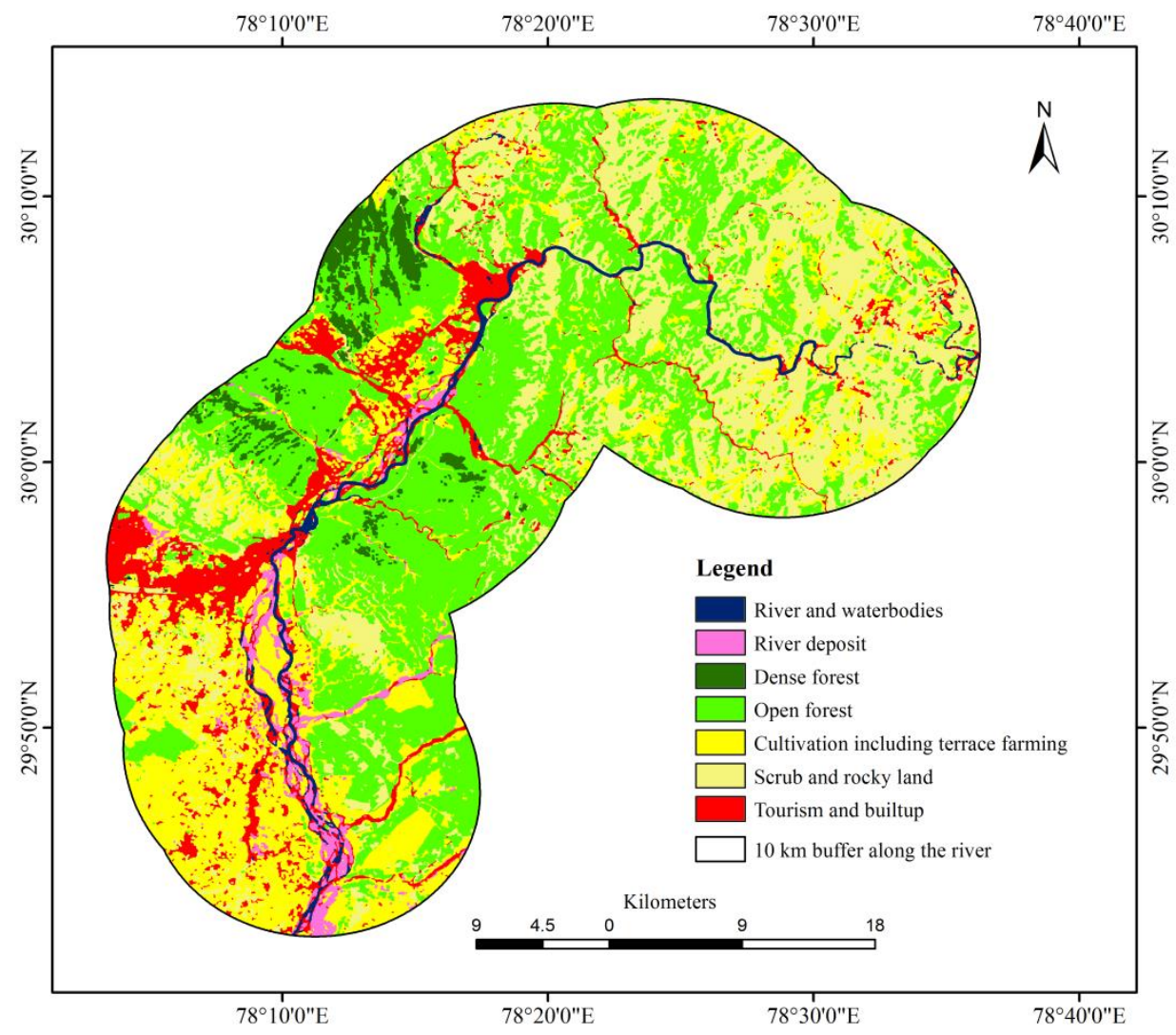

Fig. 5 Land-use map of 2020, derived from Landsat-8 OLI \& TIRS 
The change detection was then performed to identify the types of changes during the last ten years. The water samples that were collected from 5 stations along $78 \mathrm{Km}$ course of upper Ganga River. Two types buffer were created to spatial analysis the land-use change i.e. $10 \mathrm{Km}$ buffer along the river and $5 \mathrm{Km}$ buffer along with the sample collection stations and $78 \mathrm{Km}$ course of upper Ganga River (Fig. 6). The pixel-based data on land-use change was extracted for spatially correlate with WQI to test the presumption that the WQI is high where land use become changing due to human intervention.

Table 5 Details of site-wise physicochemical parameters and their QWI (mean \pm sd) during observation

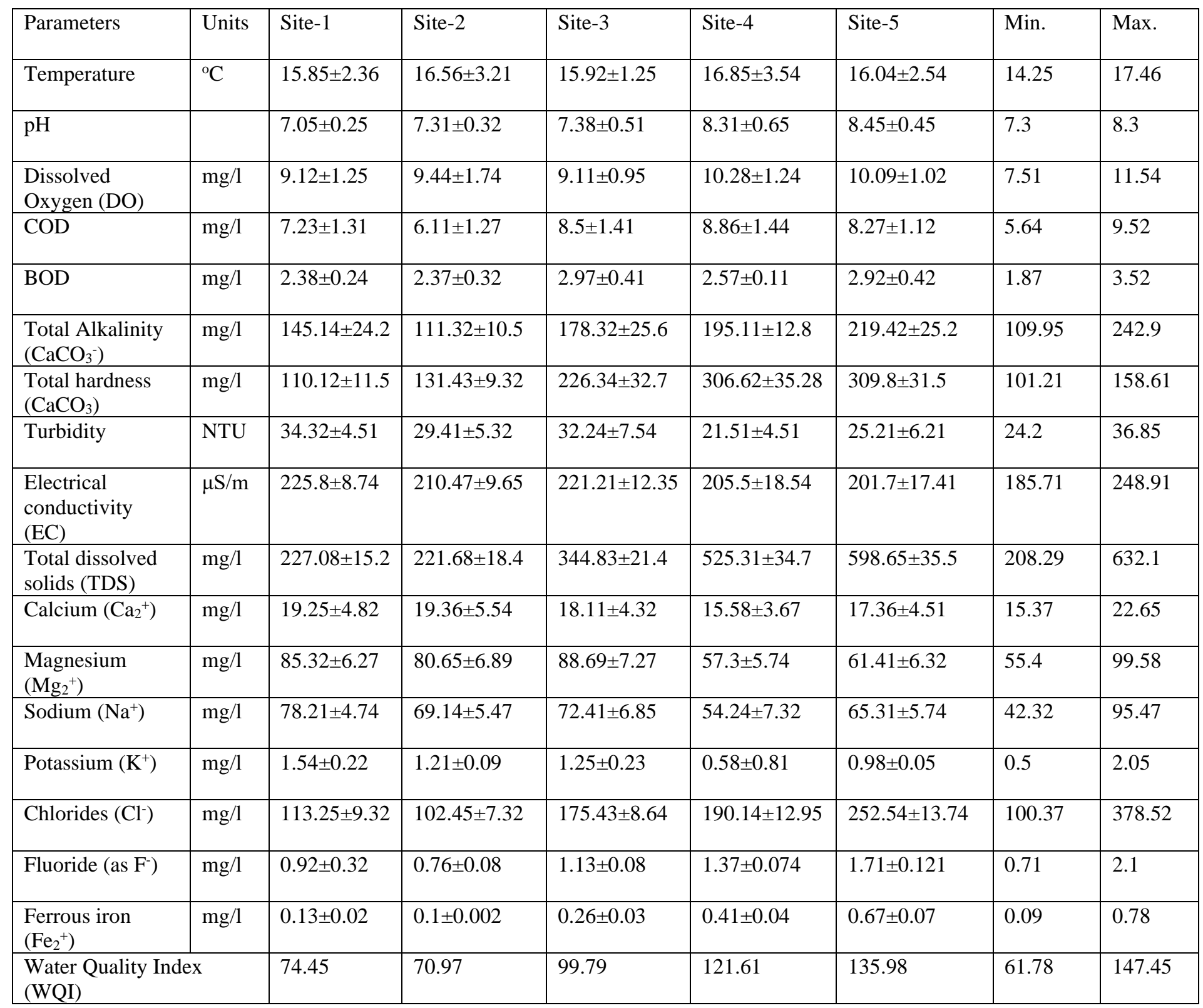




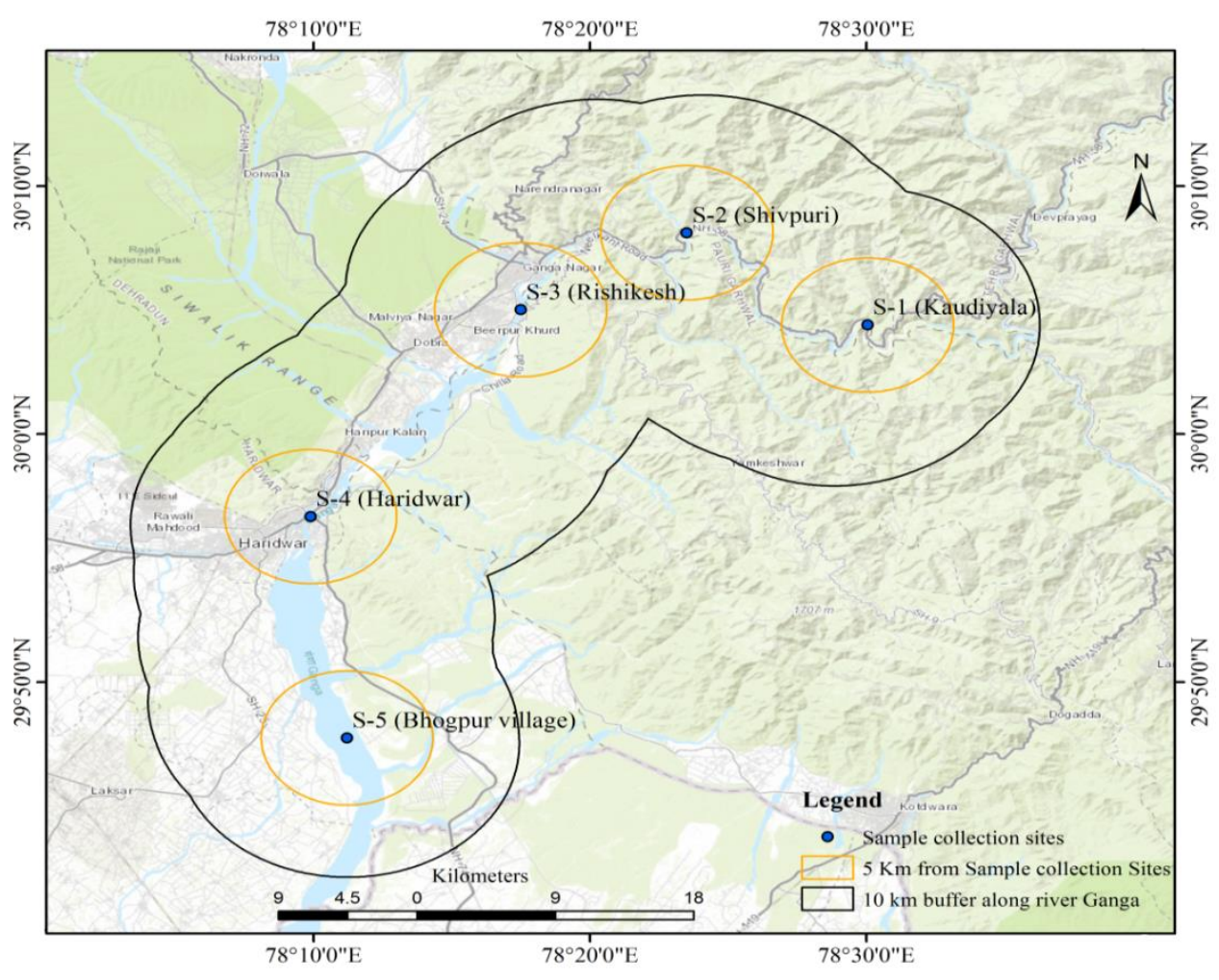

Fig. 6 The buffer distance along the case study river and sampling stations used for spatial correlation with QWI

\section{Results and Discussion}

\subsection{Physico-chemical parameters of water}

The present study aimed to analyze the human intervention on land surface and its impact on water quality. Thus, to reach such aim two-fold analysis was done. First of all water sample collection sites were chosen along the upper Ganga river to assess the water quality index and parallelly the changes on land use in that portion was detected to find correlation among human role in changing land features and deteriorating the water quality. In a short time, the present study analyzed 15 water parameters and satellite images of two periods. First water quality was analysed. Since the water contains dissolved and suspended constituents in varying proportions, it has different chemical and physical properties along with biological variation. The quality of water may be affected in various ways by pollution. The water test results on different physicochemical properties are summarized in the following table (Table 5).

The analyzed water parameters are Temperature, $\mathrm{pH}, \mathrm{DO}, \mathrm{COD}, \mathrm{BOD}, \mathrm{CaCO}_{3}{ }^{-}, \mathrm{CaCO}_{3}$, Turbidity, EC, TDS, $\mathrm{Ca}_{2}{ }^{+}, \mathrm{Mg}_{2}{ }^{+}, \mathrm{Na}^{+}, \mathrm{K}^{+}, \mathrm{Cl}^{-}, \mathrm{F}^{-}$, and $\mathrm{Fe}^{+}$. We analyzed $\mathrm{pH}, \mathrm{DO}$, Temperature and Turbidity at the sample 
collecting spot. The sample collects sterilized PVC bottle and used icebox to store the collected sample to reduce the occurring changes in water characteristics. Water temperature is a very important parameter because it influences the biota in a water body by affecting activities such as behaviour, respiration, and metabolism. The value of temperature ranges from 15.85 to $16.04^{\circ} \mathrm{C}$. It was observed that the temperature was higher during the summer, followed by rainy and winter seasons. The $\mathrm{pH}$ measures the nature of water whether it is basic $(>7)$ or acidic $(<7)$. In the present study, the highest and lowest $\mathrm{pH}$ was observed as 8.45 and 7.05 at sample site 5 and 1 respectively. High pH of water in the summer may be attributed to the utilization of free carbon dioxide in algal photosynthesis resulting in high algal population. Dissolved oxygen has a significant role in supporting aquatic life and evaluating the freshness of water. The highest DO was found at site 4 and lowest at site 3 i.e. 10.28 and $9.11 \mathrm{mg} / \mathrm{l}$ respectively. A suitable amount of DO is required in water for aquatic life like fish and another organism to maintain the diversity of all forms of life but excess amount indicates degradability of water. BOD is the amount of oxygen required during the metabolizing of organic matter and essential of the aquatic ecosystem. The Ganga water of sampled sites has the highest alkalinity $219.42 \mathrm{mg} / \mathrm{l}$ during the course of this study followed by a gradual decrease to the upper flow. The hardness of water found maximum $309.8 \mathrm{mg} / \mathrm{l}$ and the minimum $110.12 \mathrm{mg} / \mathrm{l}$ in sample site 5 and 1 respectively. The Ganga water contained the highest chemical oxygen demand $8.86 \mathrm{mg} / \mathrm{l}$ in sampled water followed by a gradual decrease to its lowest value of $6.11 \mathrm{mg} / \mathrm{l}$. some parameters like total alkalinity $\left(\mathrm{CaCO}_{3}{ }^{-}\right)$, total hardness $\left(\mathrm{CaCO}_{3}\right)$, and turbidity are found above desirable limit this is because of increasing human intervention by floating population, domestic sewage, the addition of nutrients, agricultural runoff and organic matter in water. EC of water is a direct indication of its total dissolved salts and is used for measuring the total concentration of soluble salts in water. The testing result shows that in sampling sites the concentration EC was always under the desirable limit. Although the high degree of anthropogenic activities like waste disposal, sewage, and agricultural runoff are present in site 3, 4, and 5 but EC was found in good content, it may be due to water flow towards the lower course as EC fluctuates because of water flow. Total dissolved solids (TDS) primarily contains inorganic salts like chlorides, sulphates, bicarbonates, carbonates, magnesium, sodium, potassium, phosphates, and nitrates of calcium, iron, etc. the rang of TDS shows $227.08,221.68,344.83,525.31$, and $598.65 \mathrm{mg} / \mathrm{l}$ in sample site $1,2,3,4$, and 5 respectively. The value of TDS in all sites was below the BIS desirable limit of $1000 \mathrm{mg} / \mathrm{l}$. the concentration of calcium $\left(\mathrm{Ca} 2^{+}\right)$, sodium $\left(\mathrm{Na}^{+}\right)$and potassium $\left(\mathrm{K}^{+}\right)$was also found below the desirable limit as recommended by BIS standard. But the value of magnesium $\left(\mathrm{Mg}_{2}^{+}\right)$, chlorides $\left(\mathrm{Cl}^{-}\right)$, fluoride $\left(\right.$as $\left.\mathrm{F}^{-}\right)$, and ferrous iron $\left(\mathrm{Fe}_{2}{ }^{+}\right)$were found above 
the desirable limit in some sites like 4 and 5. These parameters were found in higher proportions in this location because of the increase in pollution load by sewage and agricultural runoff in river water.

\subsection{Water quality index}

From the above data (Table 3) the water quality index was calculated for upper Ganga River at Haridwar based on sampled collection from 5 sites. The computed WQI was categorized into 5 classes i.e. excellent $(<25)$, good (25 - 50), fair (51-75), poor (76-100), very poor (101-150), and unfit for drinking $(>150)$. In the present analysis, the WQI value ranges between $121 \pm 72$. It is evident from the analysis that the WQI at site 1 (Kaudiyala) and 2 (Shivpuri) come under good to fair condition while other three sites (Rishikesh, Haridwar, and Bhogpur) fall under poor to very poor category (Fig. 7). The main reason behind the poor quality of water in Rishikesh and Haridwar are human intervention or anthropogenic activities in water, this region becoming compacted with residential hotels, shops, transportation due to human interest to come and stay in that religious place. The Bhogpur is a residential village located at a lower elevation. Here, the WQI was found very poor (135.98), it is because of high human interfere with water for agricultural purpose. The river deposits are also used here for cultivation and maximum agricultural effluents mix with river water. While site 1 and 2 (Kaudiyala and Shivpuri) have better condition and WQI was also found in good range because there are low human intervention observed and still with natural contact (Fig. 8).

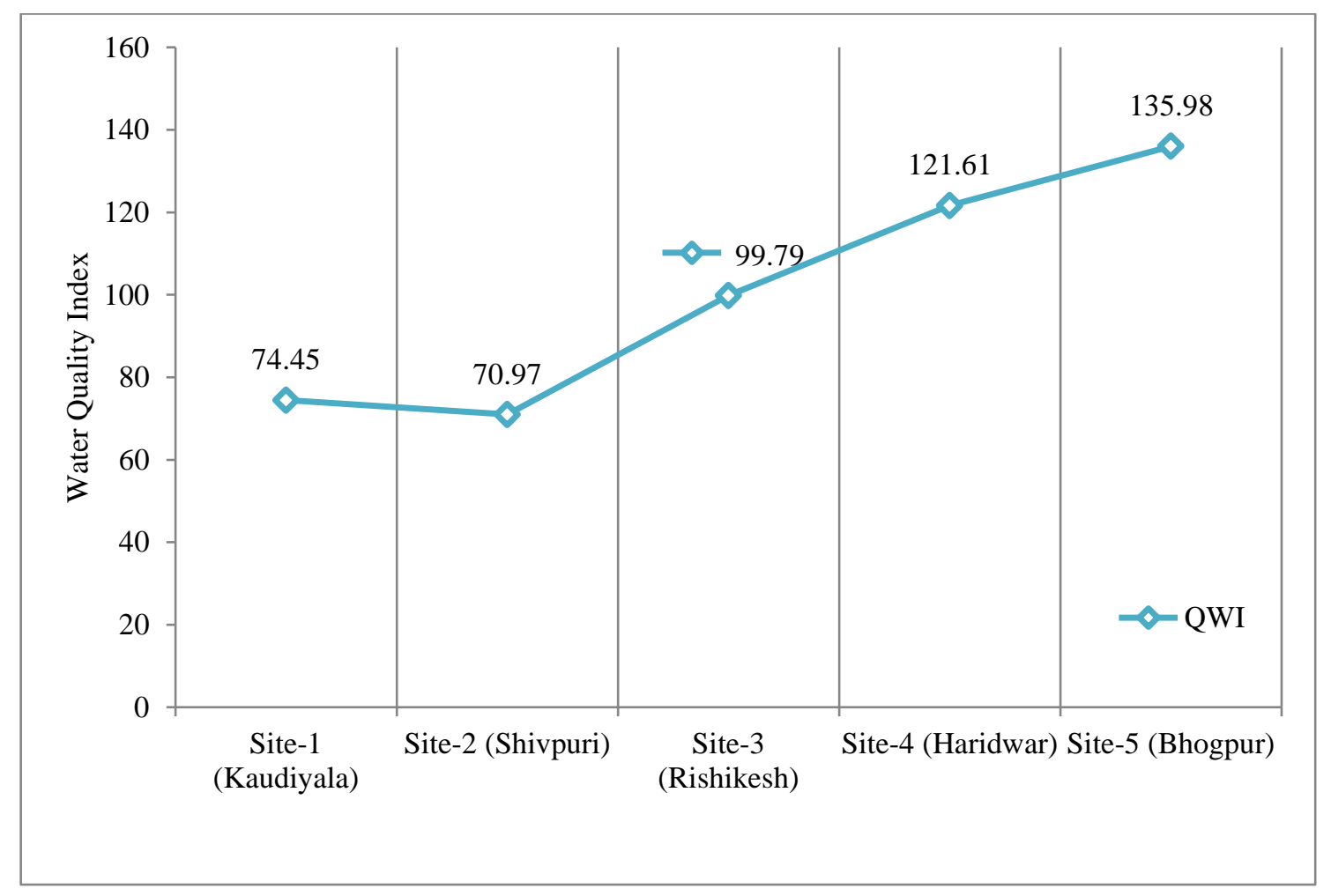


Fig. 7 Graphical representation of water quality index of selected sample sites
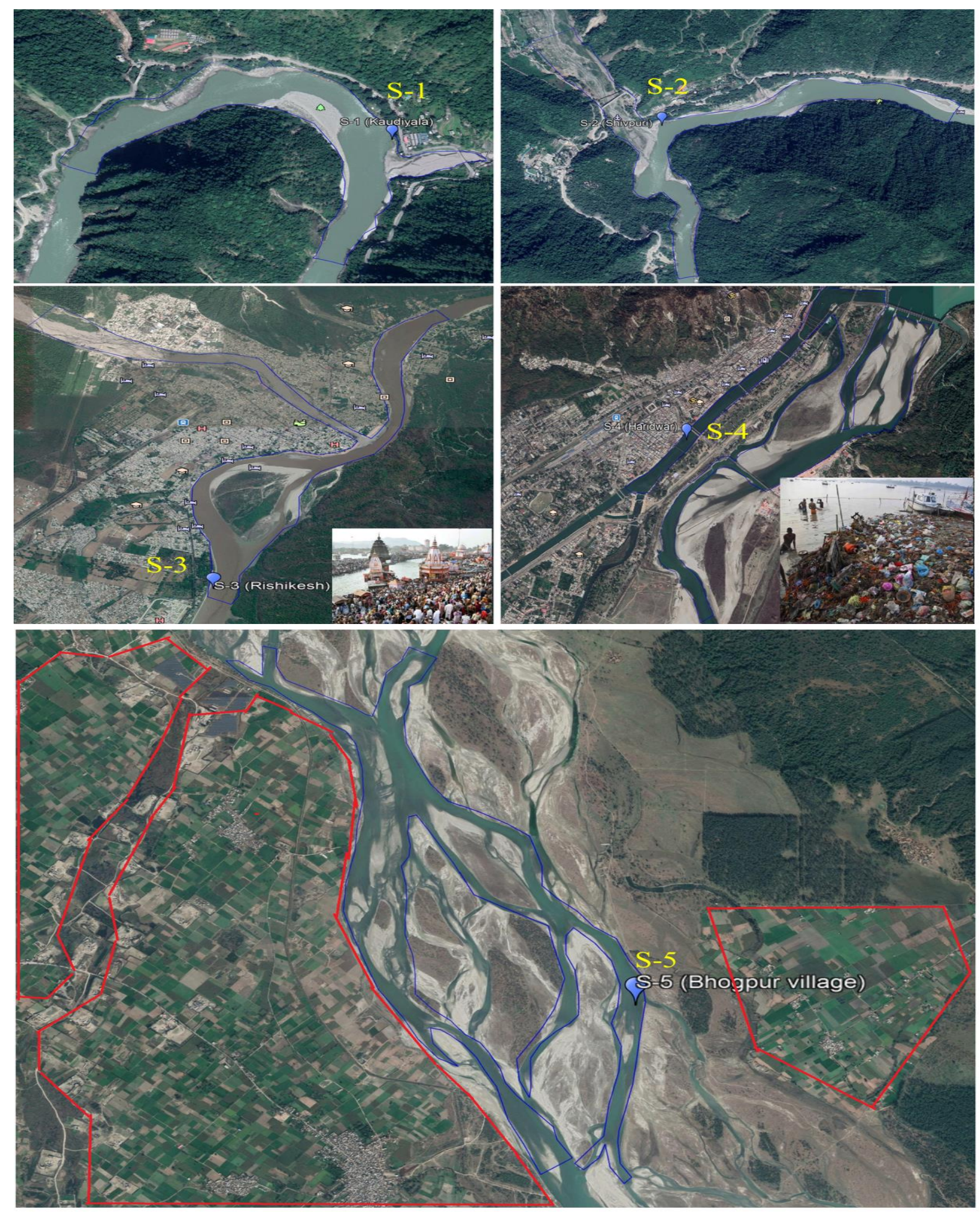

Fig. 8 High resolution recent satellite view of selected sample sites which shows the human interventions on river water and surrounding land areas (Red polygon indicates areas under cultivation) 


\subsection{Land-use change and WQI}

The area under study has faced many changes in term of land use. The pixel-based change detection of 2008 and 2018 image reveals that maximum changes occur in forest. $23.13 \%$ dense forest converted into open forest, scrub and rocky are. River and water bodies have reduced about $1.94 \%$, while cultivation including terrace farming, tourism, and the built-up area has increased by about $3.94 \%$ and $6.06 \%$ respectively (Table 6). So, as a whole, it can be said that in the last 10 years maximum land-use change in this area due to public involvement through deforestation, construction, and cultivation.

Table 6 Tabulation representation of change detection statistics of land-use from 2010-2020

\begin{tabular}{|c|c|c|c|c|c|c|c|}
\hline & $\begin{array}{l}\text { River and } \\
\text { waterbodies }\end{array}$ & $\begin{array}{l}\text { River } \\
\text { deposit }\end{array}$ & $\begin{array}{l}\text { Dense } \\
\text { forest }\end{array}$ & Open forest & $\begin{array}{l}\text { Cultivation } \\
\text { including terrace } \\
\text { farming }\end{array}$ & $\begin{array}{l}\text { Scrub and } \\
\text { rocky land }\end{array}$ & $\begin{array}{l}\text { Tourism } \\
\text { and built-up }\end{array}$ \\
\hline $\begin{array}{l}\text { River and } \\
\text { waterbodies }\end{array}$ & 13567 & 2489 & 79 & 137 & 206 & 987 & 7496 \\
\hline $\begin{array}{l}\text { River } \\
\text { deposit }\end{array}$ & 8716 & 4405 & 64 & 147 & 4103 & 1746 & 21631 \\
\hline Dense forest & 18 & 17 & 43819 & 4153 & 43 & 322 & 66 \\
\hline Open forest & 760 & 26710 & 199537 & 218345 & 2656 & 224478 & 3120 \\
\hline $\begin{array}{l}\text { Cultivation } \\
\text { including } \\
\text { terrace } \\
\text { farming }\end{array}$ & 2872 & 41349 & 2475 & 21340 & 142524 & 151170 & 37271 \\
\hline $\begin{array}{l}\text { Scrub and } \\
\text { rocky land }\end{array}$ & 3125 & 26181 & 77721 & 244238 & 18668 & 95040 & 4340 \\
\hline $\begin{array}{l}\text { Tourism and } \\
\text { built-up }\end{array}$ & 8230 & 18594 & 2105 & 4588 & 22364 & 22742 & 82845 \\
\hline Total pixel & 37288 & 119745 & 325800 & 492948 & 190564 & 496485 & 156769 \\
\hline Class change & 23727 & 115369 & 281981 & 274603 & 48044 & 401465 & 73924 \\
\hline $\begin{array}{l}\text { Change } \\
\text { detection } \\
2010-2020\end{array}$ & -12547 & -79094 & -277443 & 183001 & 208619 & -26963 & 4748 \\
\hline $\begin{array}{l}\text { Class change } \\
2010-2020 \\
(\%)\end{array}$ & $\begin{array}{l}1.94625108 \\
6\end{array}$ & $\begin{array}{l}9.46335573 \\
5\end{array}$ & $\begin{array}{l}23.1300133 \\
8\end{array}$ & $\begin{array}{l}22.5248192 \\
7\end{array}$ & 3.940898014 & $\begin{array}{l}32.930909 \\
6\end{array}$ & $\begin{array}{l}6.06375290 \\
9\end{array}$ \\
\hline
\end{tabular}

This changing phenomenon of land use has superimposed and correlated with WQI to make a conclusion about how much human activity responsible for deteriorating the natural quality of river water. The area under maximum change was extracted to put the WQI value and to fit the presumption that land-use change has been affecting the quality of water (Fig. 9). The spatial assimilation shows that Rishikesh, Haridwar, and Bhogpur 
village are under maximum human control. Seasonal religious gathering, religious mela, tourist activities and cultivation continuously occurring here which have a great burden on the water of Ganga. Excluding Kaudiyala and Shivpuri, the mean water quality index was found near and above 100 which are unfit for human use and irrigation also because contamination can deposit through the food chain and causes long term health problems.

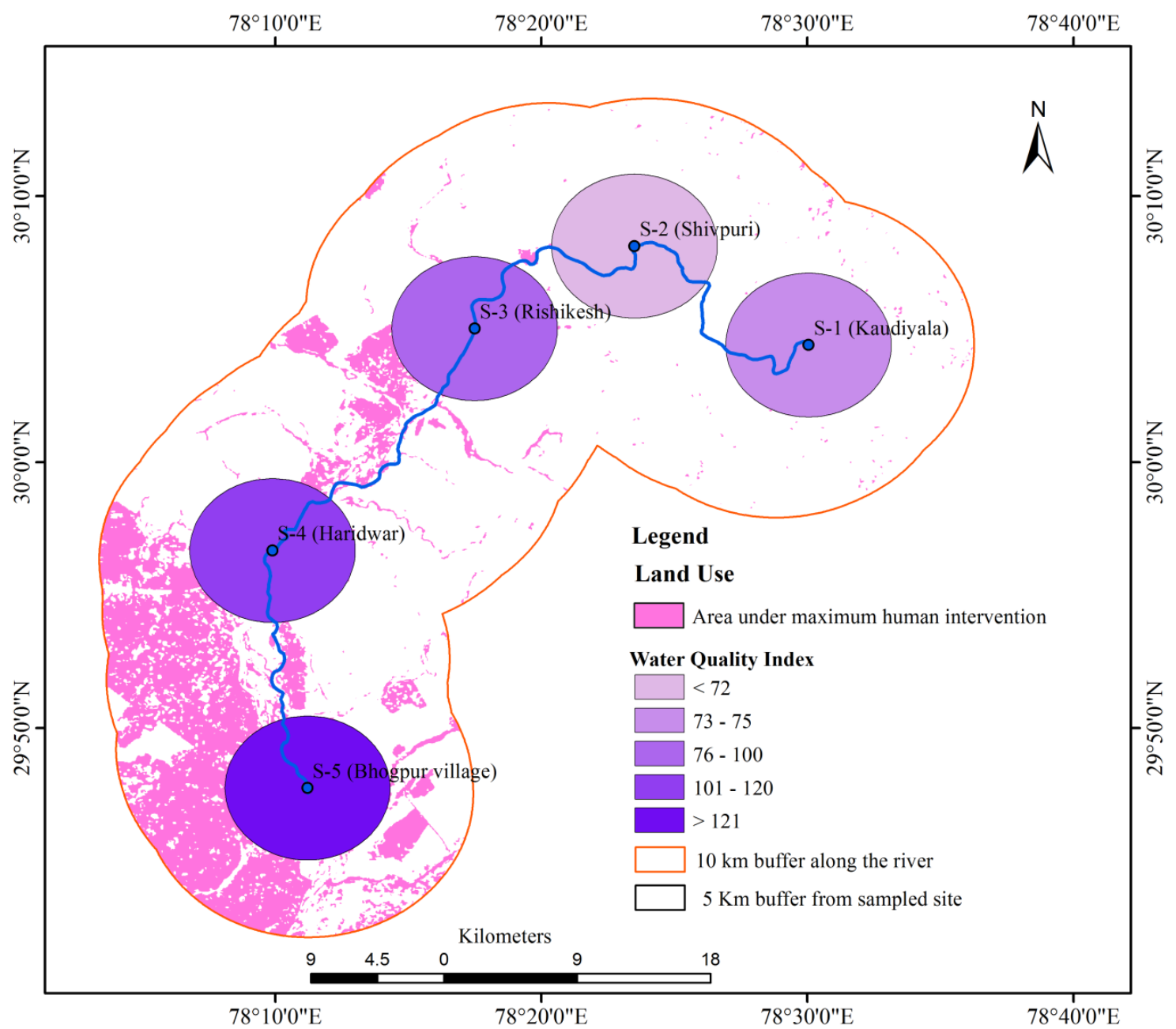

Fig. 9 Overlay image shows the spatial correlation between area under human interventions and respective water quality index of river water at upper Ganga river.

Our study findings suggest that human intervention in land-use change had significant impacts on the water quality of the study area. The physicochemical analysis of water parameters reveals that the quality of water not satisfied in those areas where maximum land under human interventions. Land use under natural forest cover acts as nutrient retention which offers rich biological system for water and aquatic life [53]. But opposite results appear with high anthropogenic inputs $[54,55]$. Concomitantly, breakdown of the natural system and land-use change has a significant role in total dissolved solids, nitrogen and phosphorous deposition which may highly be 
influenced by both point and non-point source pollution [56]. The high concentration of $\mathrm{Mg}_{2}^{+}, \mathrm{Na}^{+}, \mathrm{K}^{+}, \mathrm{Cl}^{-}, \mathrm{F}^{-}$, and $\mathrm{Fe}_{2}{ }^{+}$are also indicated a large amount of sewage and agricultural wastes discharge into the river in the study sites without proper treatment. Similar findings also found from previous studies that water quality highly influenced by untreated wastes [57-59].

Land use change has diversified types of impact on local temperature, natural ecosystem, socio-economic drivers, and even on policy making and implementation [60- 63]. Several studies emphasized on the relationship between land-use change and seasonal change of water quality [64- 67]. Although we analyzed here the mean result, but the water quality varies in the dry and rainy season, pre and post-religious gathering which is direct evidence of the role of anthropogenic activities. The water quality becomes poor during the dry season than rainy time because in dry season the river is in low flow and is more affected by point source pollutants but these become mobile with increasing velocity of river water during the rainy season [68].

However, in our findings, the tourism, built-up and agricultural land use explained the spatial differentiation in water quality index in the study area. The similar findings were general observations throughout the world [6971]. It is evident the presumption of the present study that land-use change and human intervention have a great impact on water quality due to increasing human pressure and agricultural effluents.

\subsection{Assessment and validation}

The extent of land-use change and its role in deteriorating water quality was correlated spatially. The result reveals that the water quality is poor where maximum human interventions are involved. Out of five sampled sites, two were found where QWI more than 100 (restricted for irrigation and unfit for drinking purpose) and these sites come under a maximum land-use change in last ten year. Pixel-based values were taken for assessing the accuracy of the result and testing the presumption. The root mean square error (RMSE) and mean absolute percentage error (MAPE) were considered here for the same. The pixel-based land-use change was taken as an independent variable $(\mathrm{x})$ and respective water quality as the dependent variable (y) and their error were calculated to weight the result. Statistically, RMSE is the square root of mean square error (MSE), it is expressed as:

$$
M S E=\frac{\Sigma(x-y)^{2}}{n}
$$

Where, $\mathrm{x}$ and $\mathrm{y}$ are the independent and dependent variables respectively and $\mathrm{n}$ is the number of variables. Consequently, MAPE was also considered which is the summation value of absolute error (d) is divided by a total number of variables. It can be expressed as: 


$$
M A P E=\Sigma d / n
$$

For assessing and validation of the present analysis, the pixel-based root mean square error was considered between the area of high human intervention and water quality index of respective sample sites (Table 7).

Table 7 Error estimation statistics for spatially correlate the land-use and water quality index

\begin{tabular}{|c|c|c|c|c|c|c|c|c|}
\hline Class change & Pixel count & $\begin{array}{l}\text { Maximum } \\
\text { change between } \\
\text { sampled sites }\end{array}$ & $\begin{array}{l}\text { Land use } \\
\text { change } \\
(\mathrm{p} / \mathrm{t})\end{array}$ & $\begin{array}{l}\text { change in } \\
\text { WQI (d/100) }\end{array}$ & error & $\begin{array}{l}\text { absolute } \\
\text { error }\end{array}$ & $\begin{array}{l}\text { square } \\
\text { of error }\end{array}$ & $\begin{array}{l}\text { absolute value of } \\
\text { error / actual } \\
\text { vale }\end{array}$ \\
\hline $\begin{array}{l}\text { River and } \\
\text { waterbodies }\end{array}$ & 23727 & Negligible & -- & -- & -- & -- & -- & -- \\
\hline River deposit & 115369 & S4 to S5 & 0.0946 & 0.1437 & 0.0491 & 0.0491 & 0.0024 & 0.5191 \\
\hline Dense forest & 281981 & S3 to S4 & 0.2313 & 0.2181 & -0.0131 & 0.0131 & 0.0001 & 0.0569 \\
\hline Open forest & 274603 & $\mathrm{~S} 3$ to $\mathrm{S} 4$ & 0.2252 & 0.2181 & -0.0071 & 0.0071 & 0.00001 & 0.0316 \\
\hline $\begin{array}{l}\text { Cultivation } \\
\text { including terrace } \\
\text { farming }\end{array}$ & 48044 & S4 to S5 & 0.0394 & 0.1437 & 0.1043 & 0.1043 & 0.01089 & 2.6480 \\
\hline $\begin{array}{l}\text { Scrub and rocky } \\
\text { land }\end{array}$ & 401465 & S1 to $S 2$ & 0.3293 & 0.0347 & -0.2945 & 0.2945 & 0.0867 & 0.8944 \\
\hline $\begin{array}{l}\text { Tourism and } \\
\text { built-up }\end{array}$ & 73924 & S3 to S4 & 0.0606 & 0.2181 & 0.1574 & 0.1574 & 0.02480 & 2.5971 \\
\hline
\end{tabular}




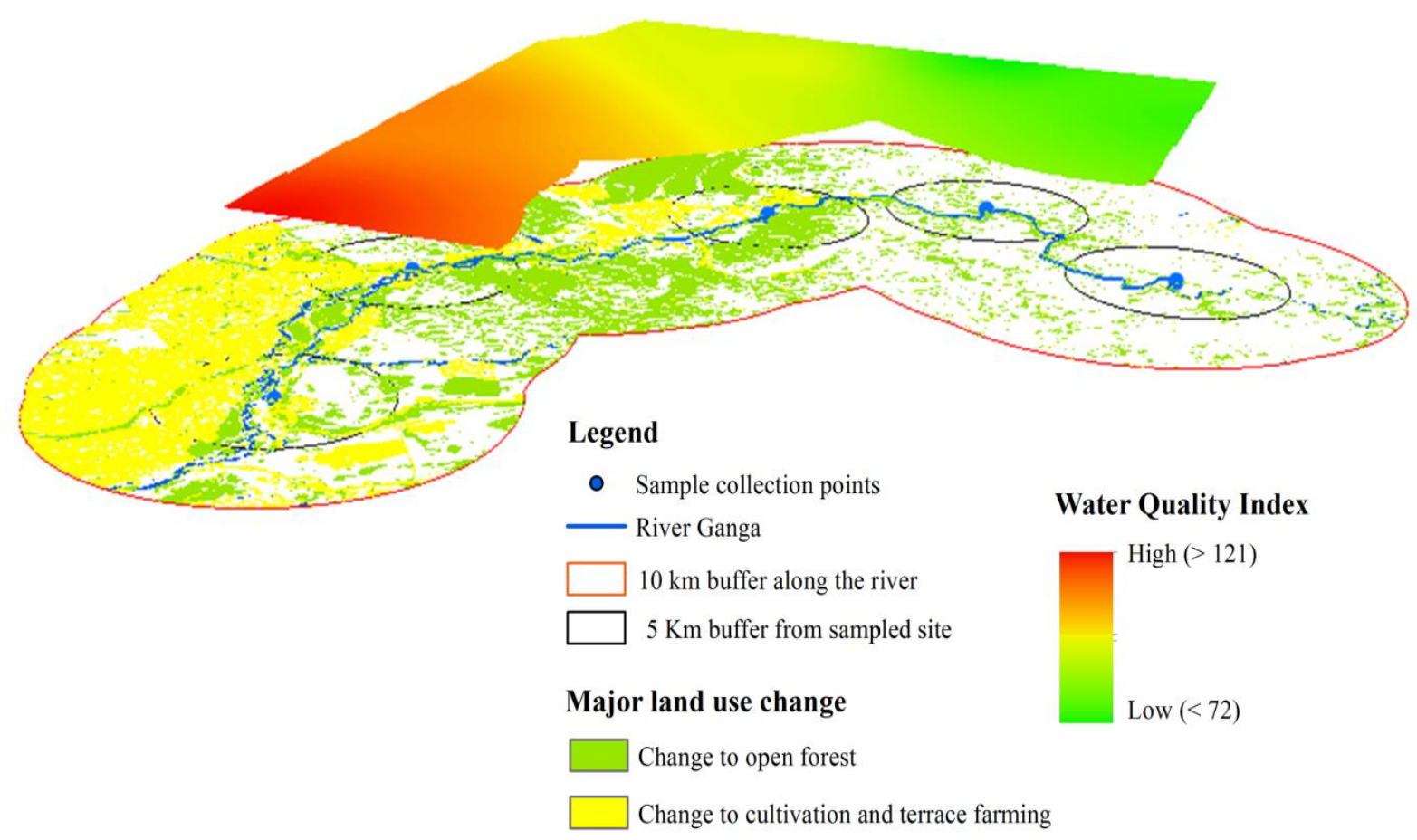

Fig. 10 Spatial overlay and scene view of land-use change and water quality index

The result from error calculation reveals that the RMSE between spatial land use and water quality index of selected sampled sites is 0.1443 , the MAPE is 1.1245 . The recorded water quality index observed not good in sample sites 3,4 , and 5 . The spatial overlay illustrates the same that these sites are under human intervention by deforestation, cultivation, terrace farming and other uses that make pollutants discharge to river water (Fig. 10).

(r)

Fig. 11 Spatially correlation between pixels based land-use change and site-wise differences in water quality index. 
The correlation between pixels based land-use change $(x)$ and site-wise differences in water quality index (y) has resulted in a high positive correlation with $\mathrm{R}^{2}=0.8455$ (Fig. 11). The degree of positive correlation has strongly indicated acceptance of the presumption and result. It is also evident from the above figure that the land-use class like cultivation and terrace farming has comparatively less change in last 10 years than scrub and rocky land, but the WQI has very high in that class. Consequently, the pixel area under tourism and built-up has also high WQI. Hence, from the error estimation and spatial correlation analysis, it was found that human interventions have a severe impact on water quality.

\section{Conclusion}

The present study was an attempt to investigate the impacts of human interactions and activities on water quality. The complex presumption was taken into consideration that the changing land use phenomena due to human intervention may responsible for deteriorating the quality of water in the upper course of river Ganga. For the same water samples were collected for testing the physicochemical properties from predefined stations by considering places with minimum and maximum human interventions observed including construction, tourism, deforestation, and cultivation. GIS technique was used for preparing land use mapping and change detecting to spatially correlate with water quality index. The result reveals that out of five selected sampled sites, three (Site 3, 4, and 5) are under human controls and maximum human engagement in land modification like road construction, habitation, religious togetherness, deforestation and cultivation that impose maximum pressure on river water directly or indirectly, where the water quality also found poor to very poor condition. The spatial autocorrelation also shows a highly positive correlation with value 0.8455 . The present investigation is also evidenced that temporarily changes in land use and human interaction with the natural system have a great impact on surface water quality, which resulted in deteriorating the water quality index that makes water unfit for irrigation and other usage.

Our study findings have demonstrated that spatial and temporal investigation through GIS and multivariate statistical techniques could offer an overview of the relationship between land use and water quality. Study findings also show that GIS has great efficacy which can correlate and analyze the spatial relations from least to large scale. It is evidenced that public interventions have a great role in changing land features as well as surface water quality. So, it is a keen interest to plan some management implications which could offer remedial measure to the level of such pollution in upper Ganga River and make it acceptable for drinking water quality standard and other usages. 


\section{Suggestions}

The following suggestions can be effective in this regards:

(i) Site-based water quality analysis in our study indicates that agricultural land use and human gathering for religious purpose affects water quality. Therefore, water restoration in critical areas should be employed for improving the quality

(ii) Deforestation should be strictly restricted and engagement of local community in preserving the forest which could improve the nutrients composition in water and enrich the overall quality of water

(iii) Major pollutants to river in the study area are derived from human wastes and agricultural effluents. Therefore, it is essential to develop effective sewage conveying system and efficient water treatment plants in affected and critical areas

(iv) Great human gathering and bathing are the main issue at Rishikesh (Site-3) and Haridwar (Site-4) due to religious faith. So, measurable Government actions should be exerted which could reduce the public interventions in water.

(v) Last but not least, more public concern, awareness and active participation should require at the local level to save the water and enrich the quality of life.

Conflict of interest: The authors declare that they have no conflict of interest

\section{References}

1. Withers, P.J:, Jarvie, H.P. (2008) Delivery and cycling of phosphorus in rivers: A review. Sci Total Environ. 2008, 400, 379-395.

2. Chen, J:, Lu, J. Effects of Land Use, Topography and socio-economic factors on river water quality in a mountainous watershed with intensive agricultural production in east China. 2014. PLoS ONE. https://doi.org/10.1371/journal.pone.0102714.

3. Abler, D:, Shortle, J:, Carmichael, J:, Horan, R. Climate change, agriculture, and water quality in the chesapeake bay region. Clim Chang, 2002, 55, 339-359.

4. Kang, J., Lee, S.W:, Cho, K.H:, Ki, S.J:, Cha, S.M:, Kim, J.H. Linking land-use type and stream water quality using spatial data of fecal indicator bacteria and heavy metals in the Yeongsan river basin. Water Res. 2010, 44, 4143-4157. 
5. Rai, B. Pollution and conservation of Ganga river in modern India. Intl J Sci Res Pub. 2013, 3 (4):1-4

6. Sharma, M:, Tobschall, H:, Singh, I. Environmental impact assessment in the Moradabad industrial area (rivers Ramganga-Ganga interfluve), Ganga Plain, India. Environ Geol. 2003, 43, 957-967

7. Kulshrestha, H:, Sharma, S. Impact of mass bathing Ardh Kumbha on water quality stutus of river Ganga. J Enviorn Biol. 2006. 27, 437-440

8. Singh, M:, Singh, A.K. Bibliography of environmental studies in natural characteristics and anthropogenic influences on the Ganga river. Environ Monit Assess. 2007. 129, 421-432

9. Paul, D; Sinha, S.N. Isolation and characterization of a phosphate solubilizing heavy metal tolerant bacterium from river Ganga, West Bengal, India Songklanakarin. J Sci Technol. 2015, 37. 651-657

10. Paul, D:, Sinha, S.N. Isolation and characterization of a phosphate solubilizing heavy metal tolerant bacterium from river Ganga, West Bengal, India Songklanakarin. J Sci Technol. 2015, 37, 651-657

11. Conley, K:, Clum, A:, Deepe, J:, Lane, H:, Barbara, B. Wastewater treatment plants as a source of microplastics to an urban estuary: Removal efficiencies and loading per capita over one year. Water Research X 3, 2019. 100030 https://doi.org/10.1016/j.wroa.2019.100030

12. Hamilton, L. What Are the Impacts of Himalayan Deforestation on the Ganges-Brahmaputra Lowlands and Delta? Assumptions and Facts. Mountain Research and Development, 1987, 7(3):256-263. https://doi.org/10.2307/3673202.

13. Maurya, P. K:, Malik, D. S. Distribution of heavy metals in water, sediments and fish tissue (H. fossilis) in Kali river of western U.P. India, Int. J. Fishries Aqua. Stu. 2016, 4, 208-215.

14. Agrawal, A:, Pandey, R.S:, Sharma, B. Water pollution with special reference to pesticide contamination in India. J Water Resour Prot. 2010, 2, 432-448.

15. Kumar, D:, Malik, D.S:, Varsha, G. Seasonal assessment of surface water quality in the middle stretch of river Ganga for suitability of fish and human health. Journal of Experimental Zoology, India, 2018. 21(2), 667-677.

16. Maurya, P.K:, Malik, D.S. Bioaccumulation of heavy metals in tissues of selected fish species from Ganga river, India, and risk assessment for human health. Hum Ecol Risk Assess. 2019, 25, 4, 905-923 https://doi.org/10.1080/10807039.2018.1456897

17. Sanchez, E:, Colmenarejo, M.F:, Vincente, J. Use of the water quality index and dissolved oxygen deficit as simple indicators of watersheds pollution. Ecol Indic. 2007, 7, 315-328. 
18. Maurya, P.K:, Malik, D.S:, Yadav, K.K:, Amit, K:, Sandeep, K:, Kamyab, H. Bioaccumulation and potential sources of heavy metal contamination in fish species in River Ganga basin: Possible human health risks evaluation. Toxicology Reports. 2019, 6, 472-481.

19. Nautiyal, C.S. Scientific validation of incorruptible self-purificatory characteristic of Ganga water. Asian Agri-History, 2009a, 13, 53-56.

20. Maurya P.K., Malik D.S., Accumulation and distribution of organochlorine and organophosphorus pesticide residues in water, sediments and fishes, Heteropneustis fossilis and Puntius ticto from Kali river, India, J. Toxicol. Environ. Health Sci. 2016, 8, 30-40.

21. Trivedi, R.C. Water quality of the Ganga River - An overview. Aquatic Ecosystem Health \& Management, 2010. 13(4):347-351, https://doi.org/10.1080/14634988.2010.528740.

22. Biswas, S.P., Boruah, S. Ecology of the river Dolphin (Platanista Gangetica) in the upper Brahmaputra. Hydrobiologia, 2000, 430, 97-101.

23. Kumar, A:, Bisht, B.S:, Joshi, V.D:, Singh, A.K:, Talwar, A. Physical, chemical and bacteriological study of water from rivers of Uttarakhand. Journal of Human Ecology, 2010, 32, 169-173.

24. Matta, G. A study on physico-chemical Characteristics to assess the pollution status of river Ganga in Uttarakhand. Journal of Chemical and Pharmaceutical Sciences, 2014, 7(3):210-217

25. Haritash, A.K:, Gaur, S:, Garg, S. Assessment of water quality and suitability analysis of River Ganga in Rishikesh, India. Appl Water Sci. 2016, 6, 383. https://doi.org/10.1007/s13201-014-0235-1.

26. Beg, K.R:, Ali, S. Chemical contaminants and toxicity of Ganga river sediment from up and down stream area at Kanpur. Am J Environ Sci. 2008, 4, 362-366

27. Gupta, A., Rai, D.K:, Pandey, R.S:, Sharma, B. Analysis of some heavy metals in the riverine water, sediments and fish from river Ganges at Allahabad. Environ Monit Assess. 2009, 157, 449-458.

28. Joshi, D.M:, Bhandari, N.S:, Kumar, A:, Agrawal, N. Statistical analysis of physicochemical parameters of water of River Ganga in Haridwar district. Rasayan Journal of Chemistry, 2009, 2(3), 579-587.

29. Rai, P.K:, Mishra, A:, Tripathi, B.D. Heavy metal and microbial pollution of the River Ganga: A case study of water quality at Varanasi. Aquatic Ecosystem Health \& Management, 2010, 13(4):352-361, https://doi.org/10.1080/14634988.2010.528739.

30. Vega, M:, Pardo, R;, Barrado, E:, Debán, L. Assessment of seasonal and polluting effects on the quality of river water by exploratory data analysis. Water Res. 1998, 32, 3581-3592. 
31. Tong, S.T.Y:, Chen, W. Modeling the relationship between land use and surface water quality. J Environ Manag, 2002, 66, 377-393.

32. Strayer, D.L:, Beighley, R.E:, Thompson, L.C:, Brooks, S:, Nilsson, C:, Pinay, G:, Naiman, R.J. Effects of land cover on stream ecosystems: Roles of empirical models and scaling issues. Ecosystems. 2003, 6, 407-423.

33. Allan, J.D. Landscapes and riverscapes: The influence of land use on stream ecosystems. Ann Rev Ecol Syst, 2004, 35, 257-284.

34. White, M.D:, Greer, K.A. The effects of watershed urbanization on the stream hydrology and riparian vegetation of Los Peñasquitos Creek, California. Landsc Urb Plan. 2006, 74, 125-138.

35. Lee, S:, Hwang, S:, Lee, S:, Hwang, H:, Sung, H. Landscape ecological approach to the relationships of land use patterns in watersheds to water quality characteristics. Landsc Urb Plan, 2009, 92, 80-89.

36. Khan, N:, Mathur, A:, Mathur, R. A study on drinking water quality in Laskhar (Gwalior). Indian J Env Prot, 2004, 25(3), 220-224

37. Kumar, P:, Kaushal, R.K:, Nigam, A.K. Assessment and management of ganga river water quality using multivariate statistical techniques in India. Asian Journal of Water, Environment and Pollution, 2015, 12(4), 61-69.

38. Maurya, P.K:, Malik, D.S. Bioaccumulation of xenobiotics compound of pesticides in riverine system and its control technique: a critical review, J. Ind. Pollut. Control, 2016, 32 (2) 580-594.

39. Dwivedi, S:, Mishra, S:, Tripathi, R.D. Ganga water pollution: A potential health threat to inhabitants of Ganga basin. Environment International. 2018, 117, 327-338. https:// doi.org /10.1016/ j.envint. $\underline{2018.05 .015 .}$

40. The Hindu Ganga. Action Plan bears no fruit. Chennai, India. Archived. 2004, https:// www.thehindu. com/todays-paper/tp-national/tp-newdelhi/ganga-action-plan-bears-nofruit/article27660726.ece

41. Kaur, B. Namami Gange: 5 reasons why Ganga will not be clean by 2020. Down To Earth. Archived, 2019. https://www. downtoearth.org.in/ coverage /water/namami-gange-5-reasons-why-ganga-will-notbe-clean-by-2020-61891.

42. Trivedy, R.K:, Goel, P.K. Chemical and Biological Methods for Water Pollution Studies, Environmental Publication, Karad (India).1986. UBS publisher.

43. American Public Health Association (APHA) Standard method for examination of water and wastewater, $21^{\text {st }}$ ed. 2005. APHA, AWWA, WPCF, Washington. 
44. Bureau of Indian Standards (BIS). Indian standard drinking water specification (second revision) BIS 10500:2012, New Delhi.

45. BIS. Indian Standard Specification for Drinking Water, IS: 10500, Bureau of Indian Standards, 1998. New Delhi.

46. Ravi kumar, P., Mohammad, Aneesul, Mehmood, M.A:, Somashekar, R.K. Water quality index to determine the surface water quality of Sankey tank and Mallathahalli lake, Bangalore urban district, Karnataka, India. Appl Water Sci, 2013, 3, 247-261. https://doi.org/10.1007/s13201-013-0077-2.

47. Malik, D.S:, Maurya, P.K.:, Heavy metal concentration in water, sediment, and tissues of fish species (Heteropneustis fossilis and Puntius ticto) from Kali river, India, Toxicol. Environ. Chem. 2015, 96, $1195-1206$.

48. Krishna, K.Y:, Kumar, S:, Quoc, B.P:, Gupta, N:, Rezania, S:, Kamyab, H:, Yadav, S:, Jan, V:, Kumar, V:, Doan Quang Tria, D.Q:, Amirreza, T:, Shiv, P:, Lisa, M. R:, Neeraja, S:, Maurya P.K.:, Jinwo, C. Fluoride contamination, health problems and remediation methods in Asian groundwater: A comprehensive review Ecotoxicology and Environmental Safety, 2019, 182, 109362

49. Avvannavar, S.M:, Shrihari, S. Evaluation of water quality index for drinking purposes for river Netravathi, Mangalore, South India. Environmental Monitoring and Assessment. 2008, 143, (1-3): 279-290. https://doi.org/10.1007/s10661-007-9977-7.

50. Paul, D:, Sinha, S.N. Assessment of various heavy metals in surface water of polluted sites in the lower stretch of river Ganga, West Bengal: a study for ecological impact. Discov Nat 2013, 6, 8-13.

51. Fathi, E:, Zamani, Ahmad, M.R:, Zare, Bidaki, R. Water quality evaluation using water quality index and multivariate methods, Beheshtabad River, Iran. Applied Water Science, 2018, 8, 210 https://doi.org/10.1007/s13201-018-0859-7.

52. Gardner, K.K:, Mc,Glynn, B.L. Seasonality in spatial variability and influence of land use/land cover and watershed characteristics on stream water nitrate concentrations in a developing watershed in the Rocky Mountain West. Water Resour Res, 2009, 45, 1-14.

53. Nakagawa, Y:, Iwatsubo, G. Water chemistry in a number of mountainous streams of East Asia. J Hydrol, 2000, 240, 118-130,

54. Piatek, K.B:, Christopher, S.F:, Mitchell, M.J. Spatial and temporal dynamics of stream chemistry in a forested watershed. Hydrol Earth Syst Sci, 2009, 13, 423-439. 
55. Ding, J:, Jiang, Y:, Fu, L:, Liu, Peng, Q.Q:, Kang, M. Impacts of Land Use on Surface Water Quality in a Subtropical River Basin: A Case Study of the Dongjiang River Basin, Southeastern China. Water 2015, 7, 4427- 4445. https://doi.org/10.3390/w7084427.

56. Dudgeon, D. Endangered ecosystems: A review of the conservation status of tropical Asian rivers. Hydrobiologia 1992, 248, 167-191.

57. Ho, K.C:, Hui, K.C. Chemical contamination of the East River (Dongjiang) and its implication on sustainable development in the Pearl River Delta. Environ Int, 2001. 26:303-308.

58. Jiang, Y:, Ding, Z:, Peng, Q:, Liao, J:, Lv, L. Spatial Distribution and Corresponding Factors of Heavy Metals Concentrations in the Dongjiang River Basin, Southeast China. Res J Env Earth Sci, 2012, 4, $448-459$.

59. Quintas-Soriano, C:, Castro, A.J:, Castro, H:, García, Llorente, M. Impacts of land use change on ecosystem services and implications for human well-being in Spanish drylands. Land Use Policy 2016, $54,534-548$.

60. Geneletti, D., Zardo, L. Ecosystem-based adaptation in cities: An analysis of European urbanclimate adaptation plans. Land Use Policy, 2016, 50- 38-47.

61. Liu, Y:, Feng, Y:, Zhao, Z:, Zhange, Q:, Su, S. Socioeconomic drivers of forest loss and fragmentation: A comparisonbetween different land use planning schemes and policy implications. Land Use Policy, 2016, 54, 58-68.

62. Nayak, S:, Mandak, M. Impact of land use and land cover changes on temperature trends over India. Land Use Policy. 2019, 89, 104-238.

63. Johnson, L:, Richards, C:, Host, G:, Arthur, J. landscape influences on water chemistry in midwestern stream ecosystems. Freshwater Biol, 1997, 37, 193-208.

64. Sliva, L:, Williams, D.D. Buffer zone versus whole catchment approaches to studying land use impact on river water quality. Water Res, 2001, 35, 3462-3472.

65. Petry, J:, Soulsby, C:, Malcolm, I.A:, Youngson, A.E. Hydrological controls on nutrient concentrations and fluxes in agricultural catchments. Sci Total Environ, 2002, 294, 95-110.

66. Yates, A.G:, Brua, R.B:, Corriveau, J:, Culp, J.M:, Chambers, P.A. Seasonality driven variation in spatial relationships between agricutural land use and in-stream nutrient concentrations. River Res Appl, 2014, 30, 476-493. 
67. Ali, S.A:, Ahmad, A. Analysing water-borne diseases susceptibility in Kolkata Municipal Corporation using WQI and GIS based Kriging interpolation. GeoJournal, 2019, https://doi.org/10.1007/s10708$\underline{019-10015-3}$

68. Woli, K.P:, Nagumo, T:, Kuramochi, K:, Hatano, R. Evaluating river water quality through land use analysis and N budget approaches in livestock farming areas. Science of Total Environment. 2004, 329, 61-74.

69. Malik, D.S:, Maurya, P.K:, Kumar, H:, Alteration in haematological indices of Heteropneustis fossilis under stress heavy metals pollution in the Kali river, Uttar Pradesh, India, Int. J. Curr. Res. 2015, 7, $15567-15573$.

70. Kumar A, Jaiswal D, Watal G (2009) Studies on chemical composition and energy transformation in river Ganga at Kanpur and Varanasi due to environmental degradation. J Environ Biol 30:445-450

71. Sahu, P:, Sikdar, P.K. Hydrochemical framework of the aquifer in and around East Kolkata wetlands, West Bengal. India Environ Geol, 2008, 55, 823-835. 